\title{
Suplementation of Vitamin D in Patients with Pulmonary Tuberculosis Ethnic Batak
}

\author{
Nita Andriani Lubis ${ }^{1}$, Melviana $^{2}$, Bintang YM Sinaga ${ }^{3}$, Yahwardiah Siregar ${ }^{4}$ \\ ${ }^{1}$ Polytechnic Health Ministry of Health Medan, Indonesia \\ nita.andriani.lubis@gmail.com \\ ${ }^{2}$ Department of Pharmacology, Department of Pulmonology and Respiratory Medicine, University of Muhammadiyah Sumatera
Utara, Indonesia
Melviana@yahoo.com
}

${ }^{3}$ Faculty of Medicine, University of Sumatera Utara, Adam Malik Hospital, Indonesia

bymsinaga@yahoo.co.id

${ }^{4}$ Department of Biochemistry, Faculty of Medicine, University of Sumatera Utara, Indonesia

yahwardiah@yahoo.com

\begin{abstract}
Vitamin D has a complex action on the immune system, among other cathelicidin production stimulator which enhances phagocytosis magrofag. TB is an infectious disease which causes high mortality and morbidity in the world. Vitamin D will give the effect when it binds to its receptor (VDR). Variants VDR gene polymorphism associated with susceptibility and resistance to pulmonary tuberculosis.

Objective: to determine the effect of vitamin $D$ in patients with pulmonary tuberculosis against ethnic Batak

The study design with RCT, Ninety-two people with pulmonary TB smear positive new cases of ethnic Batak in Medan were randomized to receive 100,000 IU doses administered at 4 doses. Assessment were performed at 14, 28, 42, and 56 days. Levels of vitamin $D$ beginning and end checked with ELISA techniques and ApaI polymorphisms of genes RVD checked by PCR RFLP.

After two months of 86 patients who met the inclusion criteria as many as 40 people with vitamin $D$ intervention and 46 to placebo. Sputum conversion times faster intervention group than placebo $(p<0.05)$ with increased levels of vitamin $D$ is much different $(95.31 \%$ and placebo interventions $6.81 \%)$. 5) dengan peningkatan kadar vitamin $D$ jauh berbeda (intervensi $\mathbf{9 5 , 3 1 \%}$ dan plasebo 6,81\%). Sputum conversion based ApaI VDR gene polymorphisms in the two groups was not significant (p> 0.05).

Vitamin D proven to accelerate the conversion of sputum in the study population of patients with pulmonary TB ethnic Batak. ApaI polymorphism of the VDR gene genotype Aa and aa more conversions at 42 days while the AA genotype at 56 days.
\end{abstract}

Keywords - Vitamin D, pulmonary tuberculosis, sputum conversion, ApaI polymorphism of the VDR gene, ethnic Batak

\section{INTRODUCTION}

Tuberculosis (TB) still remains an important cause of morbidity and mortality worldwide, and Indonesia occupies the third place (10\%) after India (24\%) and China (11\%) regarding TB incidence. Environtmental and Genetic factors play important roles in the mechanisms involved in the development of tuberculosis disease. Many studies indicated that in the immune interaction between the host and Mycobacterium tuberculosis, the genetic inherited factors play a key role [2], [12], [13].

The role of vitamin D in prevention of infectious diseases has been very important. Research has stressed the important role of vitamin $\mathrm{D}$ for the immune system. Several studies have found that low levels of vitamin $\mathrm{D}$ in the body indicates the ability of the body's defense against infection with M. tuberculosis is low as well. It is known that vitamin $\mathrm{D}$ and especially its activated metabolite 1,25-dihydroxyvitamin D3 (1,25D3) may increase natural immune regulation to restrict Mycobacterium tuberculosis [3], [14], [15].

The action of vitamin $\mathrm{D}$ is mediated through binding to its nuclear receptor (VDR). VDR is a member of the steroid/thyroid hormone receptor family. Variants of VDR gene polymorphisms influenced by ethnic and geography. One of the VDR polymorphisms in the 3' untranslated region (UTR) polymorphisms is Apa I, found in intron 8, results in a $\mathrm{T} \rightarrow \mathrm{G}$ change (the $\mathrm{T}$ allele is designated ' $A$ ' while the $G$ allele is designated 'a') [4], [5], [16], [18]. 
Ethnic Batak is located in North Sumatra. ApaI polymorphism research on ethnic Batak have not been done. Therefore we conduct a clinical trial to investigate the effects of high doses of vitamin D on sputum conversion in ethnic Batak patients receiving intensive-phase antimicrobial treatment for pulmonary tuberculosis and its relationship with ApaI polymorphism of the VDR gene.

\section{MATERIALS AND METHODS}

\section{A. Subject Selection}

Case were pulmonary tuberculosis patients were recruited from several health center in Medan city and Deli serdang district, North SumateraIndonesia. Inclusion criteria were newly diagnosed pulmonary tuberculosis, positive sputum smeer, Batak ethnic, age $\geq 18$ years old, and $\mathrm{BMI}>18,5$. Exclusion criteria were HIV positive, consuming immunopressive drugs, renal failure and diabetes mellitus.

The study was approved by medicine faculty of North Sumatera University Research Ethics Committee and written informed consent was obtained from all patients. Patients were randomly assigned to receive four fortnightly doses of 100.000 IU vitamin D3 (bio-tech pharmacal,US) vs placebo $(0,14,28$, and 42 days) [6]. Before the intervention, the blood sample is taken for checking vitamin D pre levels and ApaI polymorphism of the VDR gene. The level of vitamin $\mathrm{D}$ was analysed with ELISA, while polymorphism was analysed using PCR-RFLP. Patients were followed for two months with sputum smear examination every two weeks (14 days, 28 days, 42 days, and 56 days). Sputum specimens were examined for the presence of acidfast bacilli by microscopy Blood taken back in 56 days for checking of vitamin D post levels.

\section{VDR Genotyping}

The DNA was extracted (Promega, USA) and stored at minus $20^{\circ} \mathrm{C}$. Polymerase chain reaction (PCR) and restriction fragment length polymorphism (RFLP) was used to identify ApaI polymorphism of Vitamin D Receptor gene. The primer sequences used in this study were as follows: Forward Primer: 5'- AGA GCA TGG ACA GGG AGC AAG -3' and Reverse Primer: 5'-
GCA ACT CCT CAT GGC TGA GGT CTC A . PCR conditions were as follows: denaturation at $94^{\circ} \mathrm{C}$ for $5 \mathrm{~min}$, followed by 40 cycles of PCR at $94^{\circ} \mathrm{C}(30 \mathrm{sec})$, annealing at $60^{\circ} \mathrm{C}(30 \mathrm{sec})$, and $72^{\circ} \mathrm{C}$ (30 second). Final extension was continued at $72^{\circ} \mathrm{C}$ for $5 \mathrm{~min}$. Following PCR, the amplified PCR products was digested with ApaI restriction enzyme(Thermo Scientific) at $37^{\circ} \mathrm{C}$ for 2 hours. Digested products were analyzed using electrophoresis in $2 \%$ agarose gel and ethidium bromide stains. The bands were visualyzed by Gel Documentation System.

Depending on the digestion pattern of ApaI polymorphism, individuals were scored as aa when homozygous for the presence of the Apa I site (531 bp and $214 \mathrm{bp}$ ), AA when homozygous for the absence of the ApaI site (745 bp), or Aa in case of heterozygosity (745 bp, $532 \mathrm{bp}$ and $214 \mathrm{bp}$ ).

\section{B. Statistical Analysis}

Analyses were done with SPSS (version 17.0), Significance was tested at the 5\% level. HardyWeinberg equilibrium test was done in case and control groups for ApaI and BsmI polymorphisms using the web tool HWE Testing calculator, available on line.

\section{RESULT}

We have 92 patients, 46 received antituberculosis drug with vitamin $\mathrm{D}$ and 46 received anti-tuberculosis drugs with placebo. Antituberculosis drugs given was in accordance with the DOTS program, first category: 2RHZE/4RH. Six patients (placebo groups) had no follow-up sputum culture of data, 86 patients formed the intention-to-treat population. Clinical and demographic characteristics of Patients were comparable for intervention and control groups at baseline in Table1. The result of vitamin D levels in table 2 . 
TABLE I

CLINICAL AND DEMOGRAPHIC CHARACTERISTICS OF PATIENTS

\begin{tabular}{|c|c|c|c|c|}
\hline Karakteristik & \multicolumn{2}{|c|}{ Vitamin D $(n=40)$} & \multicolumn{2}{|c|}{ Plasebo $(n=46)$} \\
\hline & $\mathbf{N}$ & $\%$ & & $\%$ \\
\hline \multicolumn{5}{|l|}{ Age } \\
\hline $18-27$ & 12 & 30 & 6 & 13,04 \\
\hline $28-37$ & 6 & 15 & 8 & 17,40 \\
\hline $38-47$ & 16 & 40 & 14 & 30,43 \\
\hline$\geq 48$ & 6 & 15 & 18 & 39,13 \\
\hline \multicolumn{5}{|l|}{ Gender } \\
\hline Male & 26 & 65 & 30 & 65,21 \\
\hline Female & 14 & 35 & 16 & 34,79 \\
\hline \multicolumn{5}{|c|}{ Baseline acid fast bacilli } \\
\hline+3 & 10 & 25 & 13 & 28,26 \\
\hline+2 & 9 & 22,5 & 25 & 54,35 \\
\hline+1 & 21 & 52,5 & 8 & 17,39 \\
\hline \multicolumn{5}{|l|}{$25(\mathrm{OH}) \mathrm{D}$ pre } \\
\hline$<20 \mathrm{ng} / \mathrm{ml}$ & 6 & 15 & 9 & 19,57 \\
\hline $20-30 \mathrm{ng} / \mathrm{ml}$ & 11 & 27,5 & 19 & 41,30 \\
\hline$>30 \mathrm{ng} / \mathrm{ml}$ & 23 & 57,5 & 18 & 39,13 \\
\hline \multicolumn{5}{|l|}{$25(\mathrm{OH}) \mathrm{D}$ post } \\
\hline$<20 \mathrm{ng} / \mathrm{ml}$ & 0 & 0 & 7 & 15,22 \\
\hline $20-30 \mathrm{ng} / \mathrm{ml}$ & 1 & 2,5 & 18 & 39,13 \\
\hline$>30 \mathrm{ng} / \mathrm{ml}$ & 39 & 97,5 & 21 & 45,65 \\
\hline
\end{tabular}

Statistical analysis showed there are differences in vitamin D levels were significantly in the intervention group with a mean value of vitamin D levels was $31.77 \pm 9.45$ and $62.05 \pm 22.07$ for each. Levels of vitamin D in this group increased very high at $95.31 \%$. The average value of vitamin $\mathrm{D}$ levels in the placebo group before and after was $26.86 \pm 7.87$ and $28.69 \pm 7.20$ for each with the rising levels of vitamin D in this group amounted to $6.81 \%$.

TABLE II

COMPARISON Of VITAMIN D LEVELS BEFORE and AFTER the INTERVENTION and PLACEBO GROUPS

\begin{tabular}{|l|c|c|c|c|}
\hline \multicolumn{2}{|l|}{ Groups } & \multicolumn{3}{|c|}{ Levels of vitamin D } \\
\cline { 3 - 4 } & & Mean & SD & p \\
\hline Pre & VitaminD & 31,77 & 9,45 & 0,01 \\
\hline & Placebo & 26,86 & 7,87 & \\
\hline & & & & \\
\hline Post & VitaminD & 62,05 & 22,07 & \multirow{2}{*}{0,00} \\
\hline & Placebo & 28,69 & 7,20 & \\
\hline
\end{tabular}

Sputum conversion in the intervention group were significantly faster $(\mathrm{p}<0.05)$ with a mean of $3.95 \pm 1.39$ weeks than placebo group $5.52 \pm 2.11$ weeks.
TABLE III

SPUTUM CONVERSION TIME INTERVENTION and PLACEBO GROUPS

\begin{tabular}{|l|c|c|c|}
\hline \multicolumn{1}{|c|}{ Groups } & N & Mean \pm SD & p \\
\cline { 1 - 3 } Vitamin D & 40 & $3,95 \pm 1,39$ & $0,000^{*}$ \\
\cline { 1 - 2 } & & & \\
\hline Placebo & 46 & $5,52 \pm 2,11$ & \\
\hline
\end{tabular}

Here are the results of electrophoresis ApaI polymorphism pulmonary TB patients ethnic Batak on $2 \%$ agarose gel.

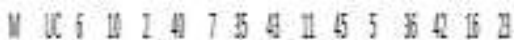

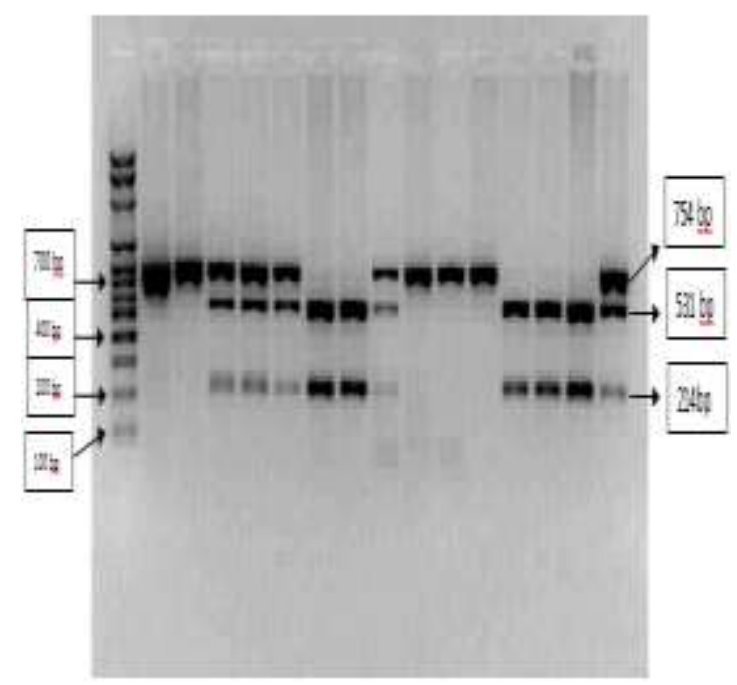

Fig.1 Result of RFLP VDR ApaI polymorphism pulmonary TB patients ethnic Batak

ApaI polymorphism genotypes AA, Aa and aa in the vitamin D group all sputum conversion to 28 days, in the placebo group sputum conversion up to 56 days.

TABLE IV

SPUTUM CONVERSION TIME RELATIONSHIP WITH APAI POLYMORPHISM VDR GENES.

\begin{tabular}{|c|c|c|c|c|c|c|c|}
\hline \multirow{2}{*}{$\begin{array}{c}\text { Geno } \\
\text { type }\end{array}$} & \multirow{2}{*}{ Groups } & \multicolumn{5}{|c|}{ Conversion time } & \multirow{2}{*}{$\mathbf{p}$} \\
\hline & & $\begin{array}{c}14 \\
\text { days }\end{array}$ & $\begin{array}{c}28 \\
\text { days }\end{array}$ & \begin{tabular}{|c|}
42 \\
days
\end{tabular} & $\begin{array}{c}56 \\
\text { days }\end{array}$ & \begin{tabular}{|c} 
No \\
conver \\
sion
\end{tabular} & \\
\hline \multirow[t]{2}{*}{$\mathrm{AA}$} & Vitamin D & 0 & $\begin{array}{c}1 \\
(50 \%) \\
\end{array}$ & $\begin{array}{c}1 \\
(50 \%) \\
\end{array}$ & 0 & 0 & \multirow[t]{2}{*}{0,978} \\
\hline & Placebo & 0 & $\begin{array}{c}2 \\
(25 \%) \\
\end{array}$ & $\begin{array}{c}3 \\
(37,5 \%) \\
\end{array}$ & $\begin{array}{c}2 \\
(25 \%) \\
\end{array}$ & $\begin{array}{c}1 \\
(12,5 \%) \\
\end{array}$ & \\
\hline \multirow[t]{2}{*}{$\mathrm{Aa}$} & Vitamin D & $\begin{array}{c}6 \\
(33,3 \%)\end{array}$ & $\begin{array}{c}9 \\
(50 \%)\end{array}$ & $\begin{array}{c}3 \\
(16,7 \%)\end{array}$ & 0 & 0 & \multirow[t]{2}{*}{0,491} \\
\hline & Placebo & $\begin{array}{c}3 \\
(16,7 \%) \\
\end{array}$ & $\begin{array}{c}7 \\
(38,9 \% \\
\end{array}$ & $\begin{array}{c}4 \\
(22,2 \%) \\
\end{array}$ & $\begin{array}{c}3 \\
(16,7 \%) \\
\end{array}$ & $\begin{array}{c}1 \\
(5,6) \\
\end{array}$ & \\
\hline \multirow[t]{2}{*}{ aa } & Vitamin D & $\begin{array}{c}4 \\
(20 \%)\end{array}$ & $\begin{array}{c}11 \\
(55 \%)\end{array}$ & $\begin{array}{c}5 \\
(25 \%)\end{array}$ & 0 & 0 & \multirow[t]{2}{*}{0,560} \\
\hline & Placebo & 0 & $\begin{array}{c}10 \\
(50 \%)\end{array}$ & $\begin{array}{c}7 \\
(35 \%) \\
\end{array}$ & $1(5 \%)$ & $2(10 \%)$ & \\
\hline
\end{tabular}




\section{DISCUSSION}

Clinical and demographic characteristics of patients were comparable for intervention and control groups at baseline (table 1). Our study show that median age did not differ significantly in two groups. This is in line with the WHO in 2012 and the Ministry of Health in 2014, the age of patients with pulmonary tuberculosis in Indonesia at most $15-44$ year amounted to $58.45 \%$. Number of TB patients was higher in certain age groups probably caused by different physiological processes at all ages, such as the role of the interaction of hormones to TB infection. Research Donald et al, 2010 stated the interaction between dehydroepiandrosterone (DHEA) and glucocorticoids that affects multiple lymphocyte function [8].

Percentage of males were higher than females TB patients.TB is more common in patients with male sex than women due to risk factors such as smoking and high alcohol consumption. Sinaga et al have shown that smoking and alcohol consumption increases the risk of pulmonary tuberculosis [9].

Vitamin D levels before and after the intervention in the two groups were increased. The mean levels of vitamin D before and after intervention in the intervention group was $31.77 \pm$ $9.45 \mathrm{ng} / \mathrm{ml}$ and $62.05 \pm 22.07 \mathrm{ng} / \mathrm{ml}$, whereas the placebo group $26.86 \pm 7.87 \mathrm{ng} / \mathrm{ml}$ and $2869 \pm$ $7.20 \mathrm{ng} / \mathrm{ml}$. Differences between the mean levels of vitamin D improved considerably by $95.31 \%$ while in the placebo group only $6.81 \%$.

The results of this study showed that the group of patients who were given vitamin D showed increased levels of vitamin D are very much different than the group who were given a placebo. Parikh, 2012 in a study stated the number of bacilli TB germs more on acid fast bacilli $(+3)$ have a higher risk of developing into a mutant drugresistant acid fast bacilli than smaller ones $(+2$ and +1) [17].

The results of this study showed the average value of sputum conversion time of study subjects in the intervention group was $3.95 \pm 1.39$ weeks, while the control group $5.52 \pm 2.11$ weeks. Sputum conversion intervention group significantly faster than placebo. Median sputum conversion time for the intervention group was 4 weeks (28 days), and placebo group of 6 weeks (42 days). RCT double blind study in Indonesia Nursyam et al, and in the UK Coosens et al, 2012 intervention of vitamin D results of sputum conversion is significantly higher in the treatment group compared with placebo [10], [11], [19].

The results of this study proved that vitamin D significantly accelerate the conversion of sputum of TB patients ethnic Batak. Giving vitamin D in patients with $\mathrm{TB}$ is highly recommended as one way to break the chain of transmission of infectious germs TB. Suplementasi vitamin D may increase the patient's immune system by inducing the cathelicidin production that play a role in fighting TB germs [2], [3], [13].

Micronutrients as potential adjunctive immunotherapy are a growing field of medical attention since scientific evidence of a specific antimycobacterial activity of vitamin D3 in macrophages has increased. These things need to be considered as one adjunctive therapy in TB cases [13].

Sputum conversion rate associated with ApaI polymorphism of the VDR gene in this study gives results that the VDR gene polymorphism Batak ApaI genotype Aa and aa in both groups were the most conversions at 28 days and at 42 days genotype AA. These results showed no difference in sputum conversion rate in both groups. Statistical analysis using the Kolmogorov-Smirnov also give the same result value of $p>0.05$ for all three genotypes which means there is no relation between sputum conversion speed with ApaI polymorphisms of VDR genes.

ApaI polymorphism of the VDR gene occur in areas that affect intron splicing process and result in disruption of the transcript. Splicing errors that occurred resulted in the formation of protein cathelicidins errors are important in the fight against TB germs.

\section{CONCLUSIONS}

Giving vitamin D on therapy Pulmonary TB in the study population of patients with pulmonary TB ethnic Batak have proven showed a significant difference in sputum conversion compared with placebo . ApaI polymorphism of the VDR gene 
genotype Aa and aa more conversions at week-6 while the AA genotype at week 8. Vitamin D should be considered as additional nutrients for each patient with pulmonary tuberculosis.

\section{REFERENCES}

[1] World Health Organization, Global Tuberkulosis Report 2014.France: Minimum graphics, pp: 21-24, 58

[2] H.K.Bid., R.Konwar, C.G. Aggarwall, Gautam, S., Saxena, M., Nayak, L., \&Banerjee, M. 2009. Reseptor vitamin D (FokI, BsmI, and TaqI) Gene Polymorphisms and Type 2 Diabetes Mellitus: A North Indian Study. India J Med Sci, 63(5), 187-190.

[3] P. Selvaraj, M. Vidyarani, M.S. Jawahar, K. Algarasu, S.P. Anand, P.R. Narayanan. 2008. Regulatory role of promoter and 3' UTR variants of reseptor vitamin $D$ gene on cytokine response in pulmonary tuberkulosis. J Clin Immunol, 28, 306-313

[4] M.R. Haussler, C.A. Haussler, L. Bartik,, G.K. Whitfield, J.C. Hsieh, S. Slater, P.W. Jurutka. 2008. Reseptor vitamin D: Molecular Signalling and Actions of Nutritional Ligands in Disease Prevention.Nutrition Reviews, 66, S98-S112

[5] G.A. Simon, D.C. Georgiana, C. Nicoleta, P.M. Daniela, S. Traian, S. Veronica. 2013. ApaI and TaqI polymorphisms of RVD (reseptor vitamin D) gene in association with susceptibility to tuberkulosis in the Romanian population. Romanian Biotechnological Letters, 18, 7956-7962

[6] A.R. Martineau, P.M. Timms, G.H. Bothamley, Y. Hanifa, K. Claxton, A.P. Claxton, G.E. Packe, J.C.M. Gillon, M. Darmalingam, R.N. Davidson, H.J. Milburn, , L.V. Baker, L.D. Barke, N.J. Woodward, T.R. Venton, K.E. Barnes, C.J. Mullett, A.K. Coussens, C.M. Rutterford, C.A. Mein, G.R. Davies, R.J. Wilkinson, V. Nikolayevsky, F.A. Drobniewski, S.M. Eldridge, C.J. Griffiths. 2011. High-dose vitamin D3 during intensive-phase antimicrobial treatment of pulmonary tuberkulosis: a double-blind randomised controlled trial. Lancet, 377, 242-50

[7] Kementerian Kesehatan Republik Indonesia. Profil Kesehatan Indonesia Tahun 2013.Jakarta:131

[8] P.R. Donald, B.J. Marais, C.E. Barry. 2010. Age and the epidemiology and pathogenesis of tuberculosis. Lancet 375: 18521854 ,

[9] Y.P. Sinaga, 2012. Ruang dan Riatual Adat Pernikahan Suku Batak Toba. Repository UI. Hal 12

[10] E.W. Nursyam, Z. Amin, C.M. Rumende. 2006. The Effect of Vitamin $D$ as Suplementary Treatment in Patiens with Moderately Advanced Pulmonary Tuberculosis Lession. Acta Medica Indonesia Journal International Medicine, 38, 3-5

[11] A.K. Coussens, R.J. Wilkinson, Y. Hanifa, V. Nikolayevsky, P.T. Elkington, K. Islam, P.M. Timms, T.R. Venton, G.H. Bethamley, G.E. Pecke, C.E. Mein, L.B. Rosun, R. Nuamah, D.B. Yang, F.A. Drobniewski, C.J. Giffiths, A.R. Martineau. 2012. Vitamin D Accelerates Resolution of Inflamatory Respons During Tuberculosis Treathment. PNAS, 109, 15449-15454

[12] C. Chen, Q. Liu, L. Zhu, H. Yang, W. Lu. 2013. Reseptor vitamin D Gene Polymorphisms on the Risk of Tuberkulosis, a Meta-Analysis of 29 Case-Control Studies. Plos One Journal, 8(12), e83843,

[13] C. Dini, and A. Bianchi. 2012. The potential role of vitamin D for prevention and treatment of tuberkulosis and infectious diseases. Ann Ist Super Sanità, 48, 319-327

[14] D.A. Jolliffe, R.T. Walton,C.J. Criffiths, A.R. Martineau. 2015. Single Nucleotide Polymorphisms In The Vitamin D Pathway Associating With Circulating Concentrations Of Vitamin D Metabolites And NonSkeletal Health Outcomes: Review Of Genetic Association Studies.Journal of Steroid Biochemistry\&Molecular Biology.4587,11

[15] K. Junaid, A. Rahman, T. Saeed, D.A. Jolliffe , K. Wood, A.R. Martineau. 2016. Vitamin D Deficiency Associates with Susceptibility to Tuberculosis in Pakistan but Polymorphisms in VDR, DBP and CYP2R1 do not.BMC Pulmonary Medicine, 16:73

[16] Y.H. Lee and G.G. Song. 2015. Vitamin D Receptor Gene FokI,TaqI,BsmI and ApaI Polymorphsms and Susceptibility to
Pulmonary Tuberculosis: a Meta Analysis.Genetics and Molecular Research.14(3):9118-9129

[17] R. Parikh, G. Nataraj, S. Kanade,V. Khatri,P. Mehta. 2012 Time to Sputum Conversion in Smear Positive Pulmonary TB Patients on Category I DOTS and Factors Delaying it.JAPI,60,22-26,

[18] J. Rashedi, M. Asgharzadeh, S.R. Moaddab, L. Sahebi, M. Khalili, M. Mazani, J. Abdolalizadeh. 2015. Vitamin D Receptor Gene Polymorphism and Vitamin D Plasma Concentration: Correlation with Susceptibility to Tuberkulosis. Advanced Pharmaceutical Bulletin,5, 1-5

[19] C. Babb, L. van der Merwe, N. Bayers, C. Pheiffer, G. Walzl, K. Duncan,P. van Hendel, E.G. Hoal. 2007. Vitamin D Receptor Gene Polymorphisms and Sputum Conversion Tine in Pulmonary Tuberculosis Patients. Tuberculosis journal, 87, 295-302,200. 